\title{
Ethics briefings
}

\section{Politics and end of life issues}

New Australian legislation has been delayed which would prohibit the sharing of information about how to commit suicide. It was held up in 2004 by opposition from some members of the Australian senate but the October elections gave the government control of the upper house, potentially allowing it to push through the new law in May 2005 when the new senate assembles. This legislation would introduce fines of up to A\$120 000 (almost $£ 50000$ ) for providing information about how people could kill themselves.

Some advice and information about suicide has been available in Australia through the organisation, Exit International, of which Dr Philip Nitschke is a prominent member. In an effort to pre-empt the legislation, he announced plans in November 2004 for a patients' handbook about a suicide pill. ${ }^{1}$ A group of patients will actually take on the task of making suicide pills from liquid barbiturates from easily available ingredients people have at home. They also intend to produce a handbook to guide other people although this will become a criminal offence once the new legislation is in place.

In the United States, one of the last official acts of Attorney General John Ashcroft in November 2004 was to request the US Supreme Court to set aside the Oregon Death with Dignity Act. A previous attempt to block the Oregon legislation by punishing doctors who prescribe lethal doses was defeated by the courts in May 2004. ${ }^{2}$ Although less prominent than the abortion debate, the issue of the Oregon assisted suicide law was seen as an important election issue for conservative Christians who helped President Bush win a second term in office. The view of the Bush administration is that assisting suicide is not a legitimate medical purpose. Ashcroft's appeal to the Supreme Court was labelled as "politically inspired" by lawyers supportive of the law who predicted that the court would refuse to intervene. ${ }^{3}$ That decision about whether or not the Supreme

All articles are written by Veronica English, Rebecca Mussell, Julian Sheather, and Ann Sommerville, BMA Ethics Department
Court will review the law is expected early in 2005.

In the UK, debate about suicide and medically assisted dying continued to generate controversy in the final months of 2004 but on this occasion it was between professional bodies. In October, the House of Lords Committee on the Assisted Dying for the Terminally Ill Bill ("the Joffe Bill") heard oral evidence from professional and regulatory bodies. These evidence sessions indicated differing approaches among professional organisations. In their evidence, the Royal College of Nursing and the British Medical Association (BMA) reiterated very strongly their traditional opposition to assisted dying. The BMA has clear policy resulting from frequent debates on the subject at its annual meeting although it also highlighted the existence of a wide range of views among the profession at large. The Royal College of General Practitioners (RCGP) and London Royal College of Physicians both withdrew their objections to the Bill, claiming neutrality and saying such issues were solely for society to decide. This was immediately hailed as a victory by the Voluntary Euthanasia Society (VES). Media including the press and the $\mathrm{BBC}^{4}$ reported that the RCGP had abandoned its previous opposition to the Bill. The College then issued a press statement expressing concern that its neutrality appeared to be exploited by euthanasia campaigners and should not be seen as tacit support. (RCGP press release. RCGP clarifies 'neutral' position on euthanasia, 15 October 2004). In its oral evidence, the General Medical Council (GMC) pointed out that its advice to doctors was simply that they should obey the law and if the law changed, GMC guidance could be adapted to reflect that. These differences seemed to perplex some members of the Parliamentary Committee who questioned whether bodies representing the medical profession could not come to a unanimous view. That seems unlikely, however, given the diversity of views among health professionals themselves.

To coincide with the professional bodies' oral evidence to the Joffe committee, the VES announced the results of a survey of 1000 UK doctors, which apparently indicated significant support for assisted suicide. It should be noted, however, that the tenor of the questions posed made such findings virtually inevitable. Respondents were invited to choose between a quick demise and lingering unrelieved suffering. No mention was made of palliative options

\section{Politics and reproductive issues}

In previous Ethics briefings challenges to current abortion legislation in the USA, Scotland, England and Wales, and Europe as a whole have been highlighted. ${ }^{567}$ The debate on abortion does not appear to be abating as highlighted in the November 2004 USA Presidential election where the topic became a key issue. Indeed contentious medical ethics issues such as abortion and embryonic stem cell research appear to be increasingly creeping into the fore of the western political arena, including Australia.

In summer 2004, in Australia, discussions around abortion drew publicity due to reports that the Health Insurance Commission was looking at Medicare fee structures to the detriment of women seeking affordable terminations. $^{8}$ Subsequently, following the Australian election in October 2004, it was reported that some Parliamentarians were considering submitting a private members bill banning post 20week gestation - "late" - abortions in the Australian Capital and the Northern Territories. ${ }^{9}$ Other reported suggestions were that women should be obliged to look at an ultrasound of the embryo/ foetus they are carrying before they made a decision to abort or not.

At the time of writing it is not clear what will be the outcome of these speculative reports although they suggest a private members bill is inevitable. The question is, if the private members bill is submitted for consideration, is it a nettle Mr Howard, the Australian Prime Minister, will want to grasp - will it be prioritised and debated?

\section{England, Wales and Northern Ireland - Impaired decision- making}

Mental capacity bill

In England, Wales, and Northern Ireland, two Bills that will have a considerable impact on individuals 
whose decision-making ability is threatened or impaired are continuing their progress through Parliament. The Mental Capacity Bill ${ }^{10}$ creates a statutory framework for decision-making on behalf of adults who do not have decision-making capacity. ${ }^{11}$ The Bill has been broadly welcomed by user groups and professionals. Some concerns have been expressed, however, that the provision for individuals to refuse life-prolonging treatment by means of an advance directive, and the power to nominate an individual with capacity to make such decisions when capacity is lost will legalise euthanasia by stealth. In contrast, supporters of the Bill believe that these aspects of the Bill have real potential to enhance decision-making freedom, and to alleviate anxieties about decision-making processes after capacity has been lost. Behind the dispute lie strong disagreements about the limit of individual decision-making autonomy. The Bill completed its Committee stage on the 4 November 2004. At the time of writing a timetable for the Bill's Report Stage had not been set.

\section{Mental health bill}

Somewhat less advanced than the Capacity Bill, and proving considerably more controversial, is the new draft Mental Health Bill. ${ }^{12}$ This new version was introduced following the withdrawal of a draft published in 2002, which was widely seen by user and professional groups as unworkable. Although the new draft introduces some welcome changes, including an explicit obligation to consult patients about their treatment, and increased protection for children and young people, it has again been met with strong criticism from user and professional groups. Of particular concern are the lack of explicit principles on the face of the Bill, which contrasts markedly with the Mental Health (Care and Treatment) (Scotland) Act $2003^{13}$ and the Bill's emphasis on controlling risk. The Bill raises a number of ethical questions, including the appropriateness of using a health instrument to manage individuals who present a risk to others but for whom no therapeutic intervention is available. The Royal College of Psychiatrists has also questioned whether the Bill is discriminatory in permitting the use of compulsory treatment where a patient retains the capacity to refuse. ${ }^{14}$ The Bill has been subjected to a period of pre-legislative scrutiny. The deadline for submission of written evidence to the Scrutiny Committee was the 4 November 2004. The Committee has to report by the end of March 2005.

\section{Council of europe} recommendations on human rights and psychiatry

It is worth noting that the United Kingdom is the only member of the 45 strong Council of Europe that reserved the right not to comply with the Council of Europe's Recommendation on Human Rights and Psychiatry, adopted in September 2004..$^{15}$ Several of the Council's Recommendations are not reflected in the new draft Mental Health Bill, including:

- The recommendation that mental disorder is defined in accordance with "international medically accepted standards" such as ICD 10 (International Classification of Diseases (10th Revision))

- The recommendation with regard to involuntary placement that "the placement includes a therapeutic purpose"

- Psychosurgery without consent is not sanctioned.

Clearly the UK's position here must raise concerns about the extent to which the draft legislation is human rights compatible.

\section{European court judgement in bournewood}

Both the Mental Capacity and Mental Health Bill have been presented with a significant challenge by the European Court of Human Rights' ruling in the Bournewood case. ${ }^{16}$ The Court found that the compliant incapacitated individual concerned - Mr L - had in fact been detained while informally treated, and that his detention was unlawful under Articles 5 (1) and 5 (4) of the European Convention. These articles relate to the deprivation of liberty and the right of access to judicial review of any such deprivation. The challenge for the Bills is to find procedural safeguards to ensure that incapacitated individuals being treated in their best interests are not arbitrarily deprived of their liberty. At the time of writing the Department of Health had announced its decision to consult on proposals for developing appropriate safeguards.

\section{New uses of IT: shared patient records}

Throughout 2004 there was much public debate about the English NHS Information Technology programme. Publication of guidance on the ambitious National Programme for Information Technology (NPfIT) is now imminent for clinicians and then the public. The guidance is due to be distributed locally in advance of one of the Programme's key deliverables-the electronic care records service.

The service essentially proposes that contemporaneous summary patient data will be placed on a national data spine. The database will be accessible to clinicians who have a legitimate clinical relationship with the patient, and at varying levels depending on the clinician's role. The national data spine has been designed on a patients opt-out model. The publications mark the start of an information campaign to inform the public of the changes and enable them to exercise their rights to opt-out.

Rebecca Mussell rmussell@bma.org.uk

\section{References}

1 Fickling D. Australians to make suicide pill. The Guardian 2004 Nov 10:20

2 English V, Mussell R, Sheather J, et al. Euthanasia: Oregon, USA. J Med Ethics 2004:30:421-422.

3 Holland G. White House wants suicide law blocked 10 Nov 2004. Newsday.com. http:// www.newsday.com/news/politics/wire/sns-apscotus-assisted-suicide, 0,2379398. story (accessed 17 Nov 2004).

4 Anon. Doctors neutral over euthanasia $15 \mathrm{Oct}$ 2004. BBC Online. http://news.bbc.co.uk/1/hi/ health/3745714.stm (accessed 17 Nov 2004).

5 English V, Mussell R, Sheather J, et al. Abortion: England, Scotland, and Wales. J Med Ethics 2004;30:517-518.

6 English V, Mussell R, Sheather J, et al. Europe: abortion. J Med Ethics 2004;30:235-236.

7 English V, Mussell R, Sheather J, et al. Abortion. J Med Ethics 2004;30:117-118.

8 Nolan T. Health Insurance Commission puts pressure on abortion providers 6 Aug 2004. ABC Online. http://www.abc.net.au/worldtoday/ content/2004/s1 170689.htm (accessed 17 Nov 2004).

9 Donald P. The World Today - doctors say antiabortion lobbyists' stats misleading 9 Nov 2004 ABC Online. http://www.abc.net.au/ worldtoday/content/2004/s $1239275 . \mathrm{htm}$ (accessed 17 Nov 2004).

10 The full text of the Bill is available at http:// www.parliament.the-stationery-office.co.uk/pa/ cm200304/cmbills/120/2004120.pdf (accessed 17 Nov 2004).

11 English V, Mussell R, Sheather J, et al. Research on incapacitated people. J Med Ethics 2004;30:421-422

12 The draft Mental Health Bill is available at http:// www.dh.gov.uk/assetRoot/04/08/89/14/ 04088914.pdf (accessed 17 Nov 2004).

13 The Act is available at http://www.scotlandlegislation.hmso.gov.uk/legislation/scotland/ acts 2003/20030013. htm laccessed 17 Nov 2004).

14 Royal College of Psychiatrists. Evidence submitted to the Joint Committee on the Draft Mental Health Bill September 2004 available at http://www.rcpsych.ac.uk/press/parliament/ responses/MHB_draft04.pdf (accessed $17 \mathrm{Nov}$ 2004).

15 The full text of the recommendation is available at http://www.coe.int/T/E/Legal_affairs/ Legal_co-operation/Bioethics/News/ Rec(2004) 10\%20e.pdf (accessed 17 Nov 2004)

$16 \mathrm{HL} \vee$ The United Kingdom, Judgment 5 October 2004, Application No.45508/99. 